\title{
Sağlık Turizmi Alanyazının Bibliyometrik Analizi (2015-2020)
}

\author{
Mehmet Halit AKIN ${ }^{1}$ \\ $\ddot{O} z$
}

Alternatif turizm faaliyeti olarak nitelendirilen sağlık turizmi, sürekli büyümekte ve sektörel olarak daha fazla ön plana çıkmaktadır. Sağlık turizminin bu denli gelişim göstermesi, araştırmacıların ilgisini çekmekte ve son yıllarda konuyla ilgili yapılmış birçok araştırma bulunmaktadır. Diğer taraftan literatürde sağlık turizmi alanında, 2015-2020 yılları arasından yayınlanmış Türkçe makalelerin bibliyometrik özelliklerinin belirlenmesine yönelik güncel bir araştırmanın bulunmamasından hareketle, bu araştırmada 2015-2020 yılları arasında sağlık turizmi alanında yapılmıs Türkçe makalelerin bibliyometrik özelliklerinin saptanması amaçlanmıştır. Araştırmanın amacı doğrultusunda, Google Scholar ve DergiPark Akademik veritabanlarında belirtilen yıllarda sağlık turizmi alanında yapılmış 102 makale tespit edilmiş ve bibliyometrik özellikleri açısından incelenmiştir. Sağlık turizmi ile ilgili bilgi birikimine yönelik özgün, detaylı ve güncel katkılar sunacak olan bu araştırmanın sonuçlarına göre, sağlık turizmi alanında yapılan makalelerin ilişkilendirilen konular, anahtar kelimeler ve yayınlandıkları dergilerin türleri bakımından çeşitlilik gösterdiği, ayrıca çok yazarlı makalelerin sayıca fazla olduğu ve disiplinlerarası işbirliğinin tercih edildiği önem arz eden bulgular olarak saptanmıştır.

Anabtar Kelimeler: Bibliyometrik analiz, Sağlık turizmi, Türkçe araştırmalar

\section{Bibliometric Analysis of Health Tourism Literature from 2015 to 2020}

\begin{abstract}
Health tourism, which is described as an alternative tourism activity, is constantly growing and is becoming more prominent as a sector. The development of health tourism attracts the attention of researchers and there have been many studies on the health tourism in recent years. On the other hand, based on the lack of an up-to-date research to determine the bibliometric properties of the Turkish articles published in the field of health tourism in the literature, this study aimed to determine the bibliometric characteristics of Turkish articles published between 2015-2020 in the field of health tourism. In line with the purpose of the study, 102 articles on health tourism in the mentioned years on Google Scholar and DergiPark Academic were identified and their bibliometric characteristics were examined. According to the results of this study, which will make original, detailed and up-to-date contributions to the body of knowledge about health tourism, it has been determined that as important findings, the articles on health tourism show variety in terms of associated subjects, keywords and the types of journals they are published, and also articles with multiple authors are numerous and interdisciplinary collaboration is preferred.
\end{abstract}

Key Words: Bibliometric analysis, Health tourism, Turkish studies

Atıf İçin / Please Cite As:

Akın, M.H. (2021). Sağlık Turizmi Alanyazının Bibliyometrik Analizi (2015-2020). Manas Sosyal Araştırmalar Dergisi, 10(3), 2026-2036.

Geliş Tarihi / Received Date: 18.02.2021

Kabul Tarihi / Accepted Date: 21.04.2021

\footnotetext{
${ }^{1}$ Dr. Öğr. Üyesi - Erciyes Üniversitesi Turizm Fakültesi, halitakin@erciyes.edu.tr

iD ORCID: 0000-0002-9455-0323
} 


\section{Giriş}

Turizm alanı, özellikle yayın bakımından sahip olduğu 70 yllı aşan geçmişiyle dünyanın en eski ve en tanınmış çalışma alanlarından birisi olarak kabul edilmektedir (Leong, Hew, Tan, Ooi ve Lee, 2020, s. 2). Diğer taraftan turizmin ulusal ve yerel ekonomiler için artan önemi ve kültürel ve sosyolojik etkileri, bir disiplin olarak gelişmesini sağlamış ve farklı disiplinlerden araştırmacıların bu alana ilgi duymasını sağlamıştır (Güzeller ve Çeliker, 2018, s. 2). Bu gelişmelerin yanı sıra bilginin nicel yönlerinin incelenmesi, bilgi ve iletişim süreçlerinin ölçülmesi ve bilimin faaliyet ve politikalarının belirlenmesinin öneminin ortaya çıkması ile birlikte uzun süreli bir geçmişe sahip olan ve önemli bir bilgi birikimi oluşan turizm araştırmalarında, bibliyometrik değerlendirmelerin önemi gittikçe artmaktadır (Hall, 2011, s. 17). Bu durum, ilgili alanyazına yansımış ve son yıllarda, turizm alanının ve alternatif turizm türlerinin bibliyometrik özelliklerinin saptanmasına yönelik birçok araştırma gerçekleştirilmiştir (Hall, 2011; Özel ve Kozak, 2012; Temizkan, Çiçek ve Cansev, 2015; Koseoglu, Rahimi, Okumus ve Lui, 2016; Boğan, Çalışkan ve Dedeoğlu, 2018; Canik ve Güneren Özdemir, 2019; Johnson ve Samakovlis, 2019; Doğan ve Baynal Doğan, 2020; Leong vd., 2020).

Araştırma alanının geçmiş makalelerin değerlendirilmesine dayalı olarak gelişimsel sürecine ilişkin genel bir bakış elde etmek, oluşan bilgi birikimi hakkında detaylı bilgiler sunmak ve gelecekteki araştırmalara öneriler sunmak bibliyometrik analizin temelini oluşturmaktadır (Johnson ve Samakovlis, 2019, s. 603). Bibliyometrik analiz, alternatif turizm faaliyeti olarak sağlık turizmi alanında da araştırmaların bibliyometrik özelliklerinin saptanması adına son yıllarda oldukça fazla tercih edilen tekniklerden birisi olmuştur (Temizkan vd., 2015; Canik ve Güneren Özdemir, 2019; Çolakoğlu, Altın ve Kıykaç, 2019; Jalali, Razak, Gordon, Perakslis ve Madnick, 2019; Oğuzbalaban, 2019; Doğan ve Baynal Doğan, 2020; Öztürk, Çoban ve Ekinci, 2020; Virani, Wellstead ve Howlett, 2020). Bu araştırmada ise son altı yllda sağlık turizmi alanında yayınlanmış Türkçe makalelerin bibliyometrik özelliklerini değerlendiren bir araştırmaya rastlanılmamış olması nedeniyle sağlık turizmi alanında 2015-2020 yılları arasında yapılmış makalelerin bibliyometrik özelliklerinin saptanması ve ilgili alanyazının detaylı bir şekilde incelenerek sağlık turizmi alanına yönelik özgün ve güncel bilgilerin sunulması amaçlanmışır.

Araştırmanın amacı doğrultusunda, 2015-2020 yılları arasında sağlık turizmi alanında elektronik olarak yayınlanmış makaleler taranmış ve tespit edilen makaleler, çeşitli parametreler bakımından incelenerek frekans ve yüzde dağılımları belirlenmesine yönelik istatistiksel analize tabi tutulmuştur. Elde edilen veriler doğrultusunda, sağılı turizmi alanının bibliyometrik özellikleri ortaya konmuş, konuyla ilgili araştırmacılara yönelik birtakım öneriler sunulmuştur. Ayrıca araştırma neticesinde elde edilecek bulguların hem var olan birtakım bilgileri güncelleyecek olması hem de 2015-2020 yılları arasında sağlık turizmi alanında yayınlanmış olan makalelere yönelik özgün bilgileri ortaya koyacak olması, bu araştırmanın ilgili alanyazına yönelik bilgi birikimine katkıların sunulması bakımından önemini ortaya koymaktadır.

\section{Literatür Taramas1}

Bireylerin daha kaliteli sağlık hizmetlerine ve tesislerine ulaşabilmenin yanı sıra gidilen destinasyonun turistik değerlerini deneyimlemek adına yapmıss oldukları seyahatler sağlık turizmi olarak tanımlanmaktadır (Görener, 2016). Son yllarda sağlık teknolojilerinde görülen gelişmeler, daha iyi sağlık hizmetlerine ve tesislerine erişme ihtiyaç ve isteğini ortaya çıkarmıştır. Diğer taraftan ulaşım ve iletişim teknolojilerinde görülen gelişmeler ise bu ihtiyaç ve isteği karşılama noktasında insanlara hem kolay ulaşım sağlama hem de hızlı ve doğru bilgiye ulaşma noktasında büyük kolaylıklar sunmuştur. Dolayısıyla alternatif turizm faaliyeti olarak görülen sağlık turizminin gelişimi kaçınılmaz olmuş ve küresel boyutta rekabetçi bir pozisyona sahip olan bir sektör olarak yerini almışır (Mahdavi, Mardani, Hashemidehaghi, ve Mardani, 2013).

Sağllk turizmi alanında son yıllarda görülen gelişmeler, bir sektör olarak sağllk turizminin ülkelerin ekonomik ve politik kararlarını yönlendirebilecek bir boyuta ulaşmasını sağlamıştır. Sağlık turizminde görülen gelişimler, sadece ekonomik ve politik anlamda değil konuyla ilgili bilgi birikimi hususunda da önemli gelişimler sağlamıştır. Diğer bir ifadeyle sağlık turizminde görülen gelişmeler, araştırmacıların ilgisini çekmiş ve konuyla ilgili birçok araştırma yapılmıştır. Bilim alanlarında görülen bu tür gelişmeler; hem ilgili bilgi birikiminin anlaşılması, değerlendirilmesi, eğilimlerin saptanması ve göstermiş olduğu gelişimin ortaya konması için o alanda yapılmış bilimsel makalelerin incelenmesinin önemini ortaya çıkarmaktadır hem de konuyla ilgili bilimsel makalelerin incelenmesine yönelik yapılan araştırmaların artış göstermesine ortam hazırlamaktadır (Kozak, 1994, s. 24). 
Bibliyometrik analiz, yazılı yayınları niceliksel olarak değerlendirmek için faydalanılan (Ellegaard ve Wallin, 2015, s. 1810) ve araştırma alanına genel bakış fırsatı sunan bir tekniktir (Bonilla Merigó ve TorresAbad, 2015, s. 1241). Bibliyometrik analiz, çalısma alanları ile ilgili atıflar, yazar bağlantıları, anahtar kelimeler, temalar, kullanılan yöntemler gibi unsurlara yönelik verileri siralayarak değerlendirme ve izlemeye yönelik faydalanılan bir yöntem olarak tanımlanmaktadır (Koseoglu vd., 2016, s. 180). Bibliyometrik çalışmalar, ayrıca belirli bir alandaki çalısmaların kalitesinin belirlenmesine, bu alandaki kavramların değerlendirilmesine ve trendlerin tanımlanmasına firsat sunmaktadır (Güzeller ve Çeliker, 2018, s. 2). Sunmakta olduğu bu firsatlardan dolayı, son yıllarda çalısma alanlarının niceliksel olarak verilerinin ortaya konması ve geleceğe yönelik önerilerin sunulması adına, bibliyometrik analiz, sağlık turizmi alanında araştırmacılar tarafindan sıklıkla tercih edilmekte ve bibliyometrik analize dayalı olarak gerçekleştirilen çalışmaların sayısı artış göstermektedir (Temizkan vd., 2015; Canik ve Güneren Özdemir, 2019; Çolakoğlu vd., 2019; Jalali vd., 2019; Oğuzbalaban, 2019; Doğan ve Baynal Doğan, 2020; Öztürk vd., 2020; Virani vd., 2020).

Temizkan vd. (2015), 1991-2014 yılları arasında sağlık turizmi alanında yapılmış Türkçe ve İngilizce makalelerin bibliyometrik profilinin incelenmesi amacıyla bir araştırma gerçekleştirmiş̧tir. Yapılan incelemeler neticesinde, sağlık turizmi alanında özellikle 2000'li yıllar sonrasında yoğunlaşma olduğu, genel çoğunluğu ampirik olmak üzere hem ampirik hem de kavramsal çalışmaların yer aldığı ve turizm ile sağlık alanında çalışan yazarların çoğunlukta olduğu tespit edilmiştir. Ayrıca coğrafya alanında çalışan yazarların da termal turizm kapsamında sağllk turizmine oldukça fazla ilgi gösterdikleri görülmüştür. Doğan ve Baynal Doğan (2020), sağlık turizminin alt bileşenleri ile ilgili makalelerin bibliyometrik analizini yapmak üzere, 2000-2019 y1llar1 arasinda SSCI (Social Science Citation Index) atıf indeksinde taranan makaleleri incelemiştir. Buna göre, en fazla kullanılan anahtar kelimenin medikal turizm kavramı olduğu, en çok atıf yapılan makalenin Connell'in (2006) çalışması olduğu ve en çok atıf alan derginin ise "Tourism Management" olduğu saptanmıştır. Ayrıca termal ve spa-wellnes turizmi ile ilgili alanyazında bir boşluğun olduğu ortaya konmuştur.

Canik ve Güneren Özdemir (2019) ise 1988-2017 yılları arasında Türkiye'de hazırlanan sağlık turizmi ile ilgili lisansüstü tezlerin bibliyometrik özelliklerini saptamak üzere bir araştırma yapmıştır. Araştırmanın amacı doğrultusunda incelenecek lisansüstü tezlerin belirlenmesi için YÖK Ulusal Tez Merkezi veri tabanında sağlık turizmi ve alt bileşenleri anahtar kelime olarak taratılmıştır. Elde edilen bulgulara göre, lisansüstü tezler de en fazla yoğunlaşılan konu termal turizm konusudur, ilgili tezlerin genel çoğunluğu sosyal bilimler enstitülerinde hazırlanmıştır ve en fazla lisansüstü tez Dokuz Eylül Üniversitesi'nde hazırlanmıştır. Ayrıca çarpıcı bir bulgu olarak, hazırlanan tezlerin anabilim dalları bakımından dağılımlarında işletme anabilim dalının birinci sırada, turizm işletmeciliği anabilim dalının ise ikinci sırada yer aldığı görülmüştür.

Öztürk vd. (2020), 1970-2020 y1lları arasında sağlık turizmi alanında en fazla atıf alan 100 İngilizce makalenin bibliyometrik özelliklerini saptamak ve kantlanabilir bilgi birikimi sunmak amactyla Web of Science üzerinde tarama yapmış ve analizler gerçekleştirmiştir. Buna göre, en çok atıf alan 100 makalenin atıf sayılarının 27 ile 361 arasında değişiklik gösterdiği, en verimli yılın 2010 ve en verimli ülkenin ABD olduğu saptanmıştır. Bununla birlikte 65 farklı dergide konuyla ilgili makalelerin yayınlandığı ve en fazla “Tourism Management" dergisinde makalenin yayınlandığı saptanmıştır. İlgili makalelere yönelik ayrıca atıf analizi yapılmış ve atıf süresinin makalenin yaşıyla ilişkili olduğu ortaya konmuştur.

Medikal turizmle ilgili politikalara yönelik yapılmış makalelerin bibliyometrik analizini gerçekleştiren Virani vd. (2020) ise bu kapsamda, Web of Science üzerinde amaca uygun mantiksal taramay1 ifade eden boolean taraması yapmıştır. Yapılan analizler neticesinde, ilgili İngilizce makalelerin yalnızca küçük bir kısmının medikal turizmle ilgili politikaları ele aldığı ve araştırma yaklaşımı olarak politika paradigmalarının uygulanmasını benimsendiği saptanmıştır. Sosyal ve sağlık alanındaki dergilerden ziyade tıpla ilgili dergilerde konuya yönelik makalelerin yayınlandığı görülmüştür. Ayrıca medikal turizm alanında yapılmış olmalarına karşın medikal turizm yönetimi ve sağlık sistemlerine yönelik politik değerlendirmelerden ziyade farklı alanların politik unsurlarına odaklanıldığı tespit edilmiştir.

\section{Yöntem}

Araştırmada, 2015-2020 yılları arasında sağlık turizmi alanında yapılmış olan Türkçe makalelerin bibliyometrik özelliklerinin saptanması, bir çalışma alanı olarak sağlık turizmi ile ilgili özgün, detaylı ve güncel bilgiler sunulması ve bu doğrultuda, sağlık turizmi alanının ayrıntılı bir şekilde incelenmesi amaçlanmıştır. Bu amaç doğrultusunda, öncelikli olarak Türkçe alanyazında sağlık turizmi alanındaki 
bilimsel makalelere yönelik yapılmış bir bibliyometrik analizinin bulunup bulunmadığı taranmış, sağlık turizmi ve çeşitleri alanında yapılmış olan lisansüstü tezlerin bibliyometrik özelliklerinin saptanmasına yönelik gerçekleştirilmiş araştırmalar tespit edilmiştir (Canik ve Güneren Özdemir, 2019; Çolakoğlu vd., 2019; Oğuzbalaban, 2019; Doğan ve Baynal Doğan, 2020). Bununla birlikte konuyla ilgili yapilmış olan Türkçe bilimsel makalelerin bibliyometrik özelliklerinin saptanmasına yönelik gerçekleştirilmiş olan tek bir araştırmaya rastlanılmıstır (Temizkan vd., 2015). İlgili araştırmada, 1991-2014 yılları arasında sağlık turizmi ile ilgili yapılmış olan makaleler analiz edilmiş olması nedeniyle bu araştırmada, 2015-2020 yılları arasında konuyla ilgili yapılmış olan makalelerin belirlenen parametrelere göre göstermiş olduğu değissim ve gelişimin ortaya konmasının önem arz ettiği düşünülmektedir.

Araştırma kapsamında, Google Scholar ve DergiPark Akademik veritabanlarında "sağlık turizmi”" kelimesi aratılarak sadece elektronik dergilerde yayınlanan makalelerin değerlendirmeye alınması araştırmanın sınırlılı̆ı̆ını oluşturmaktadır. Ancak son altı yıldaki makalelerin bibliyometrik özelliklerini saptayan bir araştırmaya rastlanılmamış olması ve 1991-2014 yıllarında yapılmış olan makalelere yönelik var olan bilgilerin, yakın geçmişi kapsayan 2015-2020 yıllarında yapılmış olan makalelerin bibliyometrik özelliklerinin saptanmasıyla güncellenecek olması bu araştırmanın önemini ortaya çıkarmaktadır. Ayrıca araştırma kapsamında incelenen Türkçe makalelerin hakem denetimli olmalarına dikkat edilmiştir.

İlgili dönemde, sağllk turizmi alanında yapılmış Türkçe makalelerin tespit edilmesi amaciyla 05.02.2021-06.02.2021 tarihleri arasinda, Google Scholar ve DergiPark Akademik veritabanlarında araştırmanın anahtar sözcüklerinden birisi olan "sağlık turizmi" kelimesi aratılarak elektronik dergiler de yayınlanan 102 Türkçe makale tespit edilmiştir. Araştırma dâhilinde, betimleyici istatistiklerden yararlanılmış olup aşağıda belirtilen parametrelere yönelik frekans ve yüzde dağglımları temel alınarak sağlık turizm alanının bibliyometrik özellikleri saptanmıştır. Bu kapsamda tespit edilen makalelerin aşağıda bahsedilen parametrelere iliş̧kin verileri, istatistiksel analiz programına aktarılmış ve analizler gerçekleştirilmiştir.

Araştırmada bibliyometrik özelliklerin saptanması amacıyla birçok farklı parametrelerden yararlanılmıştır (Özel ve Kozak, 2012; Bonilla vd., 2015; Ellegaard ve Wallin, 2015; Temizkan vd., 2015; Merigó ve Yang 2017): Makalenin yayımlandığ1 yıl, sayfa sayısı, makalenin yayınlandığ1 derginin alanı, kavramsal ya da ampirik bir çalışma olması, atıf sayısı, makaledeki yerli/yabancı atıf sayısı, makale yazarlarının sayısı, makale yazarlarının unvanları, yazarların çalıştıkları kurumlar, anahtar kelimeler yer almaktadır. Belirlenen bu parametreler doğrultusunda, araştırma kapsamında cevaplanmaya çalışılan araştırma soruları şu şekildedir: Sağlık turizmi alanına yönelik yapılmış olan makalelerin; (a) yayınlandığı yıl ve sayfa sayısı bakımından dağılımları nedir?, (b) en çok yayınlandığı dergilerin alanları hangileridir?, (c) benimsenen araştırma yöntemlerine göre durumları nedir?, (ç) toplam atıf sayısının yanı sıra yerli/yabancı dağılımı nedir?, (d) anahtar kelimelerde en çok tercih edilen kelimeler hangileridir? ve (e) yazarlarının sayı, unvan ve çalışılan kurum bakımından dağılımları nedir?.

\section{Bulgular}

Araştırma kapsamında, makalenin yayınlandığı yıl, sayfa sayısı, makalenin yayınlandığı derginin adı, kavramsal ya da ampirik bir çalışma olması, atıf sayısı, makaledeki yerli/yabancı atıf sayısı, makale yazarlarının sayısı, makale yazarlarının unvanları, yazarların çalışıkları kurumlar, anahtar kelimeler parametrelerinden yararlanılmışır. Bu kapsamda, öncelikli olarak makalelerin yayınlandığı yıllara göre dağılımlar değerlendirilmiş ve sonuçları Tablo 1'de verilmiştir.

Tablo 1. Makalelerin Yullara Göre Dağgllmlar

\begin{tabular}{c|c|c}
\hline $\boldsymbol{Y 1}$ & Makale SayıI & $\boldsymbol{\%}$ \\
\hline $\mathbf{2 0 1 5}$ & 11 & 10,8 \\
\hline $\mathbf{2 0 1 6}$ & 20 & 19,6 \\
\hline $\mathbf{2 0 1 7}$ & 16 & 15,7 \\
\hline $\mathbf{2 0 1 8}$ & 17 & 16,6 \\
\hline $\mathbf{2 0 1 9}$ & 27 & 26,5 \\
\hline $\mathbf{2 0 2 0}$ & 11 & 10,8 \\
\hline TOPLAM & 102 & 100 \\
\hline
\end{tabular}


Tablo 1'e göre, sağlık turizmi alanında yapılan makalelerin en fazla 2016 ve 2019 yıllarında yapıldığı, en az ise 2015 ve 2020 yıllarında yapıldığı görülmektedir. Sağlık turizmi alanından yapılan makaleler, niceliksel olarak yıldan yıla artış göstermekle birlikte 2020 yllında düşüş görülmüştür. Bu durum, kapsayıc1 bir başlık olarak sağltk turizminden ziyade sağlık turizminin alt bileşenleriyle ve pandeminin etkisiyle Covid-19 ile ilişkili araştırmalara bir yönelim olduğu şeklinde yorumlanabilir. İncelenen makalelerin sayfa sayılarına ilişkin dağılımlar Tablo 2'de yer verilmiştir.

Tablo 2. Makalelerin Sayfa Saynlarna İlişkin Veriler

\begin{tabular}{c|c}
\hline Sayfa Sayılart & Sayfa Sayıs \\
\hline En az & 4 \\
\hline En fazla & 39 \\
\hline Toplam & 1660 \\
\hline Ortalama & $\% 16,3$ \\
\hline
\end{tabular}

Sağlık turizmi alanında yayınlanan makalelerin toplam sayfa sayısı 1660'dır. Bu sayıya göre, analize dâhil edilen 102 makale içerisinde her bir makale başına ortalama \%16,3 sayfa sayısı düşmektedir. Bununla birlikte, en az sayfa sayısına sahip olan makalenin sayfa sayısı dört iken en çok sayfa sayısına sahip olan makalenin sayfa sayısı 39'dur. Bu noktada, makalelerin sayfa sayılarının bu denli değişiklik göstermesi ve en az ile en fazla sayfa sayısı ile ortalama değer arasında görülen farklılığın makalelerin araştırma alanlarındaki farklılıklardan kaynaklandığ görülmektedir. Sözgelimi, en az sayfa sayısına sahip olan makalenin tıp alanında olduğu ve özellikle sosyal bilimler alanında yapılan makalelerin sayfa sayılarının daha fazla olduğu görülmüştür. Sağılı turizmi alanında yayınlanan makalelerin yayınlandığı dergilere ilişkin veriler Tablo 3'de verilmiştir. Dergi türü olarak gruplandirılan "Sosyal Bilimler Dergileri”, enstitü dergilerini ve diğer sosyal bilimlerle ilişkili dergileri kapsarken "Diğer Dergiler" grubu hukuk, coğrafya, iletişim, tarih gibi alanlar ile ilişkili dergileri kapsamaktadır. "Turizm Dergileri’", "Sağlık Dergileri” ve "İ̈BF Dergileri” ise kendi alanları ve alt bileşenlerine yönelik yayın yapan dergileri kapsamaktadır.

Tablo 3. Makalelerin Yaymlandiğ Dergilere İlişkin Veriler

\begin{tabular}{c|c|c}
\hline Dergi Türleri & Dergi Sayısi & \% \\
\hline Turizm Dergileri & 16 & 15,7 \\
\hline Sosyal Bilimler Dergileri & 36 & 35,3 \\
\hline Sağlık Dergileri & 20 & 19,6 \\
\hline İ̈BF Dergileri & 12 & 11,8 \\
\hline Diğer Dergiler & 18 & 17,6 \\
\hline TOPLAM & 102 & 100 \\
\hline
\end{tabular}

Tablo 3 incelendiğinde, sağlık turizmi alanında yayınlanan makalelerin genel çoğunluğunun sosyal bilimler $(\% 35,3)$ ve sağlıkla $(\% 19,6)$ ilgili dergilerde yayınlandığ1 görülmektedir. Bu durum, sağlık turizmi alanının hem sosyal bilimler hem de sağılk alanları ile alakalı olması ile ilişkilendirilebilir. Bununla birlikte, sağlık turizmi alanında yayınlanan makalelerin 77 farklı dergide yayınlandığı tespit edilmiştir. Araştırma kapsamında incelenen makalelerin, araştırma yaklaşımlarına ilişkin veriler Tablo 4'de yer almaktadır.

Tablo 4. Makalelerin Yaklassımlarna Göre Dăğllmlarn

\begin{tabular}{c|c|c}
\hline Araştırma Yaklaşım & Makale Sayıs 1 & \% \\
\hline Kavramsal & 48 & 47,1 \\
\hline Ampirik & 54 & 52,9 \\
\hline TOPLAM & 102 & 100 \\
\hline
\end{tabular}

İncelenen makalelerin araştırma yaklaşımlarına ilişkin verilere göre, ampirik yaklaşıma başvuran makalelerin nicelik olarak çok olmasına karşın, birbirine yakın dağılımlar göstermektedir. Ampirik yaklaşıma başvuran makalelerin oranı \%52,9; kavramsal yaklaşıma başvuranların oranı ise \%47,1'dir. $\mathrm{Bu}$ durum, yeni gelişmekte olan sağlık turizmi alanında hem kavramsal bilgilerin sunumuna hem de konuyla ilgili durum tespit analizlerinin yapılmasına odaklanıldığı göstermektedir. Araştırma kapsamında incelenen makalelerin ilişkilendirilmiş oldukları konulara yönelik veriler Tablo 5’de yer almaktadır.

Tablo 5. Makalelerde Sağllk Turizmi İle İliskilendirilen Konulara İliskin Veriler 


\begin{tabular}{|c|c|c|}
\hline İliskkilendirilen Konular & Makale Sayısı & $\%$ \\
\hline Etik ve Hukuk & 3 & 2,9 \\
\hline Coğrafi Etmenler & 4 & 3,9 \\
\hline Özel ve Kamu Hastaneleri & 11 & 10,8 \\
\hline Pazarlama & 3 & 2,9 \\
\hline Bibliyometrik Analizler & 7 & 6,9 \\
\hline Rekreasyon & 2 & 1,9 \\
\hline Mevcut Durum Değerlendirmesi & 37 & 36,3 \\
\hline $\begin{array}{l}\text { Turist Memnuniyeti, Tatmini, Hizmet Kalitesi, Tercihi Etkileyen } \\
\text { Faktörler vb. Konular }\end{array}$ & 17 & 16,7 \\
\hline Diğer & 18 & 17,7 \\
\hline TOPLAM & 102 & 100 \\
\hline
\end{tabular}

Sağlık turizmi alanında yayınlanan makalelerin ilişkilendirildikleri konulara yönelik veriler incelendiğinde, makalelerin en fazla kavramsal ve ampirik olarak çeşitli destinasyonların sağlık turizmi bakımından değerlendirilmesini kapsayan "Mevcut durum değerlendirmesi” (\%36,3) ile ilişkilendirildiği görülmektedir. Bunu sırasıyla aracı kurumlar, şehir seçimi, organ nakli, tedarikçi seçimi, sağlık turisti rehberliği gibi konuları içeren "Diğer" (\%17,7) ve "Turist Memnuniyeti, Tatmini, Hizmet Kalitesi, Tercihi Etkileyen Faktörler vb. Konular" (\%16,7) ile ilişkilendirilen makaleler takip etmektedir. Genel anlamda turizmin ve alternatif turizm faaliyeti olan sağllk turizminin multidisipliner bir alan olması ve farklı alanlardan yazarların işbirliği yapıp sağlık turizmi ile ilgili araştırmalar yaptıları göz önünde bulundurulduğunda, ilişkilendirilen konularda bu denli çeşitliliğin görülmesi olağandır. Makalelerin anahtar kelimeleri bir diğer parametreyi oluşturmaktadır. Makale yazarları tarafindan en çok tercih edilen anahtar kelimelere ilişkin veriler aşağıda verilmiştir.

Tablo 6. Makalelerin Anahtar Kelimelerine İliskin Veriler

\begin{tabular}{c|c}
\hline Ilişkilendirilen Konular & Makale Sayıs \\
\hline Sağlik Turizmi & 63 \\
\hline Etik & 3 \\
\hline Termal Turizm & 33 \\
\hline Medikal Turizm & 35 \\
\hline Rekreasyon & 4 \\
\hline İleri Yaş & 10 \\
\hline Bibliyometrik & 5 \\
\hline Kaplica & 4 \\
\hline Hukuk & 3 \\
\hline Memnuniyet & 4 \\
\hline Hastane & 3 \\
\hline Coğrafya & 4 \\
\hline Pazarlama & 5 \\
\hline Hizmet Kalitesi & 5 \\
\hline
\end{tabular}

İncelenen makalelerde, insan hakları, sağllk hakk1, yeşil turizm, turist rehberliği, aracı kurumlar, tatmin, yabancı hasta, kalite, kuruluş yeri gibi kavramların yanı sıra makalelerin uygulama alanlarının, uygulama yapilan hedef kitlenin ve yararlanilan SWOT, AHP gibi yöntemlerin makalelerin anahtar kelimeleri olarak oldukça yoğun kullanıldığı görülmektedir. Bununla birlikte, makalelerde ortak olarak kullanılan anahtar kelimelere ilişkin verilerin yer aldığı Tablo 6 incelendiğinde, makalelerde en çok sırasıyla "Sağlık Turizmi" (63), "Medikal Turizm" (35) ve "Termal Turizm" (33) kavramlarının anahtar kelime olarak kullanıldıkları görülmektedir. Anahtar kelimelerdeki bu denli çeşitli olması, sağlık turizminin ilişkilendirildiği konulara paralel olarak beklenen bir husustur. Diğer taraftan "Sağlık Turizmi” kavramının birincil anahtar kelime olarak kabul edildiği, makalelerin genel çoğunluğunda anahtar kelime olarak tercih edildiği ve diğer anahtar kelimelerle birlikte kullanıldığı görülmüştür. Diğer anahtar kelimelerin ise "Sağlık Turizmi" kavramı dışında birbiriyle birlikte kullanılmadıklanı, dolayısıyla araştırmacılar tarafindan her birinin kendi makaleleri dâhilinde ikincil anahtar kelime olarak kabul edildiği saptanmıştır. İlgili makalelerin genel ve yerli/yabancı atıf sayılarına ilişkin veriler aşağıda yer almaktadır. 
Tablo 7. Makalelerin Atnf Sayzlarna Göre Dağzlımları

\begin{tabular}{c|c|c}
\hline Attf Türü & Atıf Sayıs & $\%$ \\
\hline Yerli & 1129 & 46,5 \\
\hline Yabanc1 & 1301 & 53,5 \\
\hline TOPLAM & 2430 & 100 \\
\hline
\end{tabular}

Sağlık turizmi alanında yapılan makalelerde toplamda 2430 atıf sayısının olduğu, bu atıfların \%46,5'inin yerli, \%53,5'inin ise yabancı olduğu saptanmıştır. Yabancı kaynak kullanımı, yerli kaynak kullanımına kıyasla kısmen fazla olmakla birlikte bu durum, yazarların yabancı literatürdeki kaynaklara daha fazla başvurduklarını göstermektedir. Araştırma kapsamında, yararlanılan parametrelerden bir diğeri olan makalelerin yazar sayılarına ilişkin veriler Tablo 8'de yer almaktadır.

Tablo 8. Makalelerin Yazar Sayzlarna Göre Dağzlamları

\begin{tabular}{c|c|c}
\hline Yazar Sayıları & Makale Sayıs & \% \\
\hline Tek yazarlı & 34 & 33,3 \\
\hline İki yazarlı & 42 & 41,2 \\
\hline Üç yazarlı & 20 & 19,6 \\
\hline Dört ve üzeri yazarlı & 6 & 5,9 \\
\hline TOPLAM & 102 & 100 \\
\hline
\end{tabular}

Yazar sayılarına ilişkin veriler bir bütün olarak değerlendirilmiş ve genel toplamda 205 yazarın incelenen makalelere katk1 yaptıkları saptanmıştır. Bunun yanı sıra Tablo 8'de de görüldüğü üzere, sağlık turizmi alanında yayınlanan makalelerin 42'sinin iki yazarlı (\%41,2); 20 'sinin üç yazarlı $(\% 19,6)$; altısının ise dört ve üzeri yazarlı $(\% 5,9)$ olduğu tespit edilmişsir. Makalelerin ilişkilendirilmiş oldukları konularla benzer şekilde, turizmin ve alternatif turizm faaliyeti olan sağlık turizminin multidisipliner yapısından dolayı makale yazarlarının tek yazarlıdan ziyade çok yazarlı olması normal karşılanabilir. Makale yazarlarının unvanları, bir diğer parametreyi oluşturmaktadır ve buna ilişkin veriler aşağıda verilmiştir.

Tablo 9. Makale Yazarlarnnn Unvanlarna Göre Dağgllmlarn

\begin{tabular}{c|c|c}
\hline Unvan & Yazar Sayıs & $\%$ \\
\hline Prof. Dr. & 19 & 9,3 \\
\hline Doç. Dr. & 27 & 13,2 \\
\hline Dr. Öğr. Üyesi & 62 & 30,3 \\
\hline Dr. & 14 & 6,8 \\
\hline Öğr. Gör. & 20 & 9,8 \\
\hline Arş. Gör. & 22 & 10,6 \\
\hline Lisansüstü Ö̆ğr. & 33 & 16,1 \\
\hline Diğer & 8 & 3,9 \\
\hline TOPLAM & 205 & 100
\end{tabular}

Makale yazarlarının unvanlarına ilişkin verilere göre, sağlık turizmi alanında yayınlanan makalelerde en fazla "Dr. Öğretim Üyesi” (\%30,3) ve "Lisansüstü Öğrenci” (\%16,1) unvanına sahip olan yazarların yer aldığ1 görülmektedir. En az ise uzman, memur gibi unvanları içeren "Diğer" $(\% 3,9)$ grubunda yer alan yazarlar yer almaktadır. Yazarların kurumlarına ilisskin verilere ise Tablo 10'da yer verilmiştir.

Tablo 10. Makale Yazarlarmmn Kurumlarnna Göre Dağzlamlarn

\begin{tabular}{c|c|c}
\hline Kurum Türü & Yazar Sayıs & \% \\
\hline Turizm & 69 & 33,8 \\
\hline Sağlık & 53 & 25,9 \\
\hline Coğrafya & 17 & 8,5 \\
\hline İktisadi ve İdari Bilimler & 28 & 13,4 \\
\hline Hukuk & 6 & 2,9 \\
\hline Diğer & 32 & 15,5 \\
\hline TOPLAM & 205 & 100 \\
\hline
\end{tabular}

Yazarların kurumlarına ilişkin dağılımların yer aldığı Tablo 10'a göre, sağlık turizmi alanında "Turizm" ile ilişkili kurumlarda görev yapan yazarların $(\% 33,8)$ genel çoğunlukta olduğu, bunu ise "Sağllk" $(\% 25,9)$, 
"Diğer" (\%15,5) ve "İktisadi ve İdari Bilimler" $(\% 13,4)$ ile ilişkili kurumlarda görev yapan yazarların takip ettiği görülmektedir. "Diğer" grubunda yer alan yazarların genel olarak, hukuk, mühendislik, turizmle ilişkili olmayan meslek yüksek okulları gibi kurumlarda görev yaptıkları tespit edilmiştir. Sağlık turizmi alanında yapılan makalelerin yazarlarının kurumlarına göre dağılımları, makale yazarlarının unvanlarına göre dağılımları ile benzerlik göstermektedir.

\section{Sonuç ve Öneriler}

Araştırma kapsamında, sağlık turizmi alanından 2015-2020 yıllarını kapsamak üzere son altı y1 içerisinde yapılmış olan makalelerin bibliyometrik özelliklerinin saptanması, sağlık turizmi ile ilgili özgün, detaylı ve güncel bilgiler sunulması ve sağlık turizmi alanının ayrıntılı bir şekilde incelenmesi amaçlanmıştır. Bu kapsamda, makale taraması yapılarak 102 makale analiz edilmiştir. Son altı yıldaki makalelerin bibliyometrik özelliklerini saptayan bir araştırmaya rastlanılmamış olması nedeniyle konuyla ilgili bilgi birikimine özgün katkıların sunulması ve daha öncesinde sunulmuş olan bilgilerin güncellenecek olması bu araştırmanın önemini ortaya koymaktadır.

2015-2020 yılları arasında sağlık turizmi alanında yapılan makalelere, genel çoğunluğunun çok yazarlı olmak üzere, 205 yazarın katkı sağladığı ve bu yazarların unvanlarına ilişkin genel çoğunluğu ise "Dr. Öğretim Üyesi” ve "Lisansüstü Öğrencilerin" oluşturduğu görülmüştür. Ayrıca ilgili yıllar içerisinde, yapılan makale sayısının yıldan yıla artış göstermekte olduğu ancak 2020 yılında düşüş olduğu görülmüştür. Buna göre, farklı unvanlara sahip olan yazarların yeni gelişmekte olan sağlık turizmine yönelik ilgileri yıldan yıla artış göstermiştir. Ayrıca çok yazarlı makalelerin nicelik olarak fazla olması, sağlık turizmi ile ilgili araştırmalarda disiplinlerarası işbirliğinin tercih edildiğini göstermektedir. 2020 yllındaki düşüş ise yazarların, sağlık turizmi kavramından ziyade alt bileşenlerine ve pandeminin etkisiyle Covid-19’la ilişkili araştırmalara doğru bir yönelim içerisinde oldukları ile ilişskilendirilmiştir (Anık, Korkmaz ve Bayraktar, 2020; Ankaya ve Aslan, 2020; Bölüktaş, 2020; Çakır ve Aydın, 2020; Çevrimli ve Beyhan, 2020; Çınar ve Özkaya, 2020; Baynal Doğan, Doğan ve Baynal, 2020; Gürleyen ve Çınar, 2020; Sancar ve Öngel, 2020).

Sağlık turizmi alanında yayınlanan makalelerin ilişkilendirildikleri konuların, anahtar kelimelerinin ve yayınlandıkları dergilerin çeşitlilik gösterdiği görülmüştür. İlgili üç parametre ilişkin bu sonuçlar, turizmin ve alternatif turizm faaliyeti olan sağlı turizminin multidisipliner bir alan olması ile ilişkilendirilmiştir. Makalelerin yayınlanmış olduğu dergilerde görülen çeşitlilik aynı zamanda, yukarıda da bahsedildiği üzere, sağlık turizmi ile ilgili araştırmalarda disiplinlerarası işbirliğinin tercih edilmesi ve sağlık turizmi alanının hem sosyal bilimler hem de sağlık alanları ile alakalı olması ile ilişkilendirilmiştir.

Sağlık turizmi makalelerinde, hem kavramsal bilgilerin sunulması hem de durum tespit analizlerinin yapılmasına odaklanıldığı için, ampirik çalışmalar niceliksel olarak kısmen fazla olsa da, ampirik ve kavramsal yaklaşımların her ikisinin de benimsendiği görülmüștür. Diğer taraftan toplamda 1660 sayfa sayısına ulaşan sağılk turizmi alanında yapılan makalelerde, özellikle sosyal bilimlerle ilişkili kavramsal ve ampirik yaklaşımı benimseyen makalelerin sayfa sayılarının diğer alanlara kıyasla oldukça fazla olduğu tespit edilmiştir. Yerli/yabancı atıf sayıları bakımından ise yazarların yabancı literatüre kısmen de olsa daha fazla başvurdukları saptanmıştır. Diğer taraftan sağlık turizminin alt bileşenlerinden olan ileri yaş, engelli ve yasa aşan gibi sağlık turizmi türleri ile ilişkili alanyazında bir boşluğun olduğu görülmüştür.

Araştırma kapsamında elde edilen bulguların, 1991-2014 yılları arasından sağlık turizmi alanında yapılmış olan makalelerin bibliyometrik özelliklerini ortaya çıkarmak amacıyla Temizkan vd., (2015) tarafından gerçekleştirilen araştırmanın bulguları ile kıyaslanması, ilgili literatürde görülen gelişim, değişim ve durağan durumların ortaya konması adına önem arz etmektedir. Bu noktada, ilgili araştırma ile bu araştırma da değerlendirilen ortak parametreler doğrultusunda kıyas yapılmıştır. Sözgelimi, ilgili araştırmada incelenen Türkçe makalelerde tercih edilen araştırma yaklaşımına ilişkin dağılımlar kavramsal için \%46,2, ampirik çalışmalar için ise \%53,8 olarak saptanmışır. Bu araştırmada ise kavramsal için \%47,1, ampirik çalışmalar için ise \%52,9 olarak saptanmıştır. Her iki araştırmanın bulguları genel anlamda yakın değerlere sahip olmakla birlikte, her ikisinde de ampirik çalsşmaların daha çok benimsendiği görülmektedir. Diğer taraftan araştırmacıların araştırma yaklaşımları bakımından ampirik çalışmalardan kavramsal çalışmalara yöneldikleri görülmektedir.

$\mathrm{Bu}$ araştırmada tespit edilen yayınlanan dergilerin alanlarındaki çeşitlilik durumu, Temizkan vd., (2015) tarafından yapılan araştırmada da tespit edilmiş ve turizmin yanı sıra ekonomi, İ̈BF, hukuk, antropoloji alanlarında sağlık turizmi ile ilişkili makalelerin yayınlandığı ortaya konmuştur. Diğger taraftan 
her iki araştırmanın yazarların çalışma alanlarını temsil eden kurumlarına göre dağılımlarında, çalışma alanları sadece turizmle ilişkili olan araştırmacıların değil farklı çalışma alanları ile ilişkili araştırmacıların sağlık turizmi ile ilgili araştırmalar yaptıkları görülmektedir. İlgili araştırmada, sağlık turizmi alanında çalışan araştırmacıların genel çoğunluğu temsil eden \% 20'sinin sağlık alanında, \% 19,7'sinin turizm alanında, \% 16,9'unun ise coğrafya alanında çalş̧tıkları saptanmıştır. Bu araştırmada ise \% 25,9'unun sağlık alanında, \% 33,8'inin turizm alanında, \% 8,5'inin ise coğrafya alanında çalıştıkları saptanmıştır. Buna göre, özellikle sağlık ve turizm alanlarında çalışan araştırmacıların sağılı turizminin gelişimine dayalı olarak kendi alanları ile ilişkili olan bu konuya yönelik ilgilerinin gittikçe arttı̆̆ı görülmektedir.

Sağlık turizmi alanyazını ile ilgili elde edilen bulgular, sonuçlar ve kıyaslamalar bir bütün olarak değerlendirildiğinde, sağllk turizminin ve alt bileşenlerinin gelişimi ile birlikte sağlık turizmi ile ilişkili araştırmalara yönelik ilginin de arttığı görülmektedir. Ayrıca sağlık turizminin alt bileşenleri ve diğer çalışma alanları ile ilişkili araştırmalar niceliksel olarak artış göstermektedir. Bununla birlikte disiplinlerarası bir çalışma alanı olan turizmin yansıması olarak sağlık turizmine yönelik yapılan araştırmaların ve sağlık turizmine ilgi gösteren araştırmacıların çalışma alanlarının da çeşitlilik gösterdiği anlaşılmaktadır.

$\mathrm{Bu}$ araştırmanın, sadece belirli yıllar arasındaki, elektronik dergilerde yayınlanan ve "sağlık turizmi" anahtar kelimesi dâhilinde belirlenen makalelerin değerlendirmeye alınması gibi birtakım sınırlılıkları bulunmaktadır. Dolayısıyla ilgili tarihler arasında yayınlanmış ve bu araştırma kapsamında dâhil edilmemiş olan makaleler bulunabilir. Bu doğrultuda, gelecekte benzer konuda araştırma yapacak araştırmacıların daha geniş anahtar kelimeler dâhilinde elektronik dergilerin yanı sıra basilı yayınları kapsayacak şekilde bibliyometrik özellikleri saptamaları önerilmektedir. Bununla birlikte, sağlık turizmi alanında araştırma yapacak olan araştırmacılara ise özellikle yabancı kaynakların daha fazla tercih edildiği, sağlık turizmi ile ilişkili farklı çalışma alanlarından farklı araştırmacılar ile işbirliğinin sağlandığı araştırmaların yapılması önerilmektedir. Ayrıca kavramsal ve ampirik yaklaşımla yapılacak çalışmaların niceliksel olarak artırılması önerilmekle birlikte sağlık turizminin şu an ki konumu düşünüldüğünde, sağlık turizmi ve alt bileşenleri ile ilişskili makalelerde kavramsal çalışmalardan ziyade hem uygulayıcılara hem de araştırmacılara yönelik çeşitli değişkenler bakımından önerilerin sunulması ve mevcut durumun değerlendirilebilmesi adına ampirik çalışmalara ağırlık verilmesi önem arz etmektedir. Sonuç olarak sağılı turizmi alanında yapılacak olan bu araştırmaların sağlık turizminin hem kavramsal çerçevede hem de uygulamada daha etkin bir şekilde gelişim göstermesine katk1 sağlayacak olması doğrultusunda, ileri yaş, engelli ve yasa aşan gibi sağlık turizminin alt bileşenlerine yönelik tespit edilen boşluğun hem kavramsal hem de ampirik yaklaşımlarla yapılacak araştırmalar ilgili alanyazına kazandırılması önerilmektedir.

\section{Etik Beyan}

"Sağhlk Turizmi Alammın Bibliyometrik Analizi (2015-2020)" başlıklı çalışmanın yazım sürecinde bilimsel kurallara, etik ve alıntı kurallarına uyulmuş; toplanan veriler üzerinde herhangi bir tahrifat yapılmamıs ve bu çalışma herhangi başka bir akademik yayın ortamına değerlendirme için gönderilmemiştir. Bu araştırma doküman incelemesine dayalı olarak yapıldığından etik kurul kararı zorunluluğu bulunmamaktadır.

\section{Kaynakça}

Anık, Ö. G. E., Korkmaz, Ö. G. C. B., ve Bayraktar, Ö. G. M. Türkiye'de pazarlama açısından medikal turizm ve sürdürülebilirlik. Journal of Social, Humanities and Administrative Sciences, 6(33), 1951-1960.

Ankaya, F. Ü., ve Aslan, B. G. (2020). Engelli turizm potansiyelinin değerlendirilmesi; Dünya ve Türkiye örnekleri. Ulusal Cevre Bilimleri Arasturma Dergisi, 3(2), 52-57.

Baynal Doğan, T. G., Doğan, S., ve Baynal, B. İleri yaş ve engelli turizmi hedef kitlesine yönelik Bolu ili sağlık serbest bölgesi tasarım. Ankara Hacı Bayram Veli Üniversitesi Turizm Fakïltesi Dergisi, 23(2), 295-311.

Boğan, e., Çalışkan, C., ve Dedeoğlu, B. B. (2018). Turizm yazınında kurumsal sosyal sorumluluk: Türkiye'de yapılan çalışmaların bibliyometrik analizi. Turizm Akademik Dergisi, 5(2), 47-62.

Bonilla, C. A., Merigó, J. M., ve Torres-Abad, C. (2015). Economics in Latin America: a bibliometric analysis. Scientometrics, 105(2), 1239-1252.

Bölüktaş, R. P. (2020). Türkiye'nin yaşlı sağlığı turizmi için firsatları. İstanbul Sababattin Zaim Üniversitesi Sosyal Bilimler Dergisi, 8(16), 1-15.

Canik, S., ve Özdemir, E. G. (2019). Sağlık turizmini konu alan lisansüstü tezlerin bibliyometrik değerlendirmesi (1988-2017). Anatolia: Turizm Arastrmalar Dergisi, 30(2), 125-134.

Çakır, M., ve Aydın, F. (2020). Yerel halkın termal turizme yönelik görüşleri: Haymana ilçesi örneği. Doğı Coğrafja Dergisi, 25(43), 93-110. 
Çevrimli, A. B. A., ve Beyhan, Ş. G. (2020). Termal turizm yapıları özelinde mimari kimlik analizi ve etkileşim şemasının oluşturulması: Pamukkale-Karahayıt örneği.Journal of Advanced Research in Natural and Applied Sciences, 6(2), 283-302.

Çınar, F., ve Özkaya, B. (2020). Koronavirüs (COVID-19) pandemisinin medikal turizm faaliyetlerine etkisi. Sağhk ve Sosyal Refah Araștirmalarn Dergisi, 2(2), 35-50.

Çolakoğlu, Ü., Altun, H. E., ve Kıykaç, B. (2019). Türkiye'deki medikal turizm tezlerinin bibliyometrik profili (20082018). Anatolia: Turiżm Araştırmalar Dergisi, 30(2), 135-143.

Connell, J. (2006). Medical tourism: Sea, sun, sand and... surgery. Tourism Management, 27(6), 1093-1100.

Doğan, S., ve Baynal Doğan, T. G. (2020). Uluslararası alanyazında sağlık turizmi alt bileşenleri üzerine bibliyometrik bir analiz. Hacettepe Sağlık İdaresi Dergisi, 23(4), 561-586.

Ellegaard, O., ve Wallin, J. A. (2015). The bibliometric analysis of scholarly production: How great is the impact?. Scientometrics, 105(3), 1809-1831.

Görener, A. (2016). A SWOT-AHP approach for assessment of medical tourism sector in Turkey. Alphanumeric Journal, 4(2), 159-170.

Gürleyen, B., ve Çınar, F. (2020). Türkiye'nin medikal turizm SWOT analizi: Covid-19 örneği. Sağllk ve Sosyal Refah Araştırmalar Dergisi, 3(1), 51-60.

Güzeller, C. O., e Celiker, N. (2018). Bibliometric analysis of tourism research for the period 2007-2016. Advances in Hospitality and Tourism Research, 6(1), 1-22.

Hall, C. M. (2011). Publish and perish? Bibliometric analysis, journal ranking and the assessment of research quality in tourism. Tourism Management, 32(1), 16-27.

Jalali, M. S., Razak, S., Gordon, W., Perakslis, E., ve Madnick, S. (2019). Health care and cybersecurity: bibliometric analysis of the literature. Journal of Medical Internet Research, $21(2)$, e12644.

Johnson, A. G., ve Samakovlis, I. (2019). A bibliometric analysis of knowledge development in smart tourism research. Journal of Hospitality and Tourism Technology.

Koseoglu, M. A., Rahimi, R., Okumus, F., ve Liu, J. (2016). Bibliometric studies in tourism. Annals of Tourism Research, 61, 180-198.

Kozak, N. (1994). Anatolia Dergisi’nde yayınlanan yazılar üzerine bir inceleme. Anatolia Turižm Araştırmalar Dergisi, 5(3), 22-33.

Leong, L. Y., Hew, T. S., Tan, G. W. H., Ooi, K. B., ve Lee, V. H. (2020). Tourism research progress-a bibliometric analysis of tourism review publications. Tourism Review.

Mahdavi, Y., Mardani, S., Hashemidehaghi, Z., ve Mardani, N. (2013). The factors in development of health tourism in Iran. International Journal of Travel Medicine and Global Health, 1(2), 113-118.

Merigó, J. M., ve Yang, J. B. (2017). A bibliometric analysis of operations research and management science. Omega, 73, 37-48.

Oğuzbalaban, G. (2019). Termal turizm konulu lisansüstü tezlerin bibliyometrik analizi. Türk Turizm Araștırmalarn Dergisi, 3(4), 1012-1027.

Özel, Ç. H., ve Kozak, N. (2012). Turizm pazarlaması alanının bibliyometrik profili (2000-2010) ve bir atıf analizi çalışması. Türk Kütüphaneciliği, 26(4), 715-733.

Öztürk, N., Çoban, M., ve Ekinci, E. (2020). A bibliometric analysis of the 100 top-cited publications in health tourism. International Journal of Health Management and Tourism, 5(3), 315-335.

Sancar, T., ve Öngel, V. (2020). Medikal turizm hizmeti veren sağlık kuruluşlarının rekabet stratejilerinin kurum performansına etkisi: İstanbul örneği. Third Sector Social Economic Review, 55(4), 2847-2868.

Temizkan, P. N., Çiçek, D. ve Cansev, A. (2015). Sağlık turizmi konusunda yayınlanan makalelerin bibliyometrik profili. Journal of Human Sciences, 12(2), 394-415.

Virani, A., Wellstead, A. M., ve Howlett, M. (2020). Where is the policy? A bibliometric analysis of the state of policy research on medical tourism. Global Health Research and Policy, 5, 1-16.

\section{EXTENDED ABSTRACT}

Bibliometric studies provide an opportunity to determine the quality of studies in a particular field, to evaluate the concepts in this field, and to define trends (Güzeller and Çeliker, 2018, p. 2). These opportunities make bibliometric analysis frequently preferred by researchers in order to reveal the quantitative data of study fields in recent years. The importance of bibliometric evaluations in the field of tourism has gradually increased due to the fact that the tourism field is accepted as one of the oldest and most well-known fields of study in the world with its history of more than 70 years (Leong et al., 2020, p. 2) and its long-term history and significant body of knowledge (Hall, 2011, p. 17).

In the field of health tourism as an alternative tourism activity, it has been one of the highly preferred techniques in recent years in order to determine the bibliometric properties of researches (Temizkan et al., 2015; Canik and Güneren Özdemir, 2019; Çolakoğlu et al., 2019; Jalali et al., 2019; Oğuzbalaban, 2019; Doğan and Baynal Doğan, 2020; Öztürk et al., 2020; Virani et al., 2020). Developments in health tourism have provided significant improvements in knowledge on the subject. In other words, developments in 
health tourism attracted the attention of researchers and many studies have been conducted on the subject. Such developments in science fields; It reveals the importance of analyzing scientific articles made in that field in order to understand and evaluate the relevant knowledge, to identify trends and to reveal the progress it has shown, and it also provides an opportunity to increase the number of studies conducted for the examination of scientific articles on the subject (Kozak, 1994, p. 24).

In this study, it was aimed to determine the bibliometric properties of the articles conducted between 2015-2020 in the field of health tourism and to present detailed information about the field of health tourism by examining the relevant literature in detail, since there has been no research evaluating the bibliometric properties of Turkish articles published in the field of health tourism in the last six years. In line with the purpose of the study, the articles published electronically in the field of health tourism between 2015-2020 were scanned and identified, the year the article was published, the number of pages, the area of the journal in which the article was published, whether it was a conceptual or empirical study, the number of citations, domestic / foreign citations in the article, number of article authors, titles of article authors, institutions where authors work, keywords were analyzed and subjected to statistical analysis to determine frequency and percentage distributions. The fact that the findings to be obtained as a result of the research will both update some of the existing information and reveal original information about the articles published in the field of health tourism between 2015-2020 reveals the importance of this research in terms of contributing to the knowledge of the relevant literature.

According to the findings of the study, 205 authors, most of whom were multi-authors, contributed to the articles made in the field of health tourism between 2015 and 2020, and the general majority of these authors" titles were "Dr Lecturer" and "Graduate Students". In addition, it has been observed that the number of articles produced has increased year by year over the relevant years, but has decreased in 2020. Accordingly, the interest of the authors with different titles towards the newly developing health tourism has increased year by year. In addition, the large quantity of multi-author articles indicates that interdisciplinary cooperation is preferred in research on health tourism. The decrease in 2020 has been associated with the fact that the authors are in a direction towards its sub-components rather than the concept of health tourism.

It has been observed that the articles published in the field of health tourism, the subjects they are associated with, their keywords and the journals they have been published have varied. These results, which were determined regarding the relevant three parameters, were associated with the fact that tourism and health tourism, which is an alternative tourism activity, is a multidisciplinary field. The diversity seen in the journals in which the articles were published has also been associated with the preference of interdisciplinary cooperation in research on health tourism and the relevance of the field of health tourism to both social sciences and health fields, as mentioned above.

Although empirical studies are somewhat quantitatively large, both empirical and conceptual approaches have been found to be adopted, as health tourism articles focus on both presenting conceptual information and conducting situation analysis. On the other hand, in the articles made in the field of health tourism, which reached a total of 1660 pages, it has been determined that the number of pages of the articles that adopt the conceptual and empirical approach related to social sciences are quite high compared to other fields. In terms of the number of domestic / foreign citations, it was found that the authors used more foreign literature, albeit partially.

This research has some limitations, such as evaluating only the articles published in electronic journals between certain years and determined within the keyword "health tourism". In this direction, it is recommended that researchers who will conduct research on similar subjects in the future should determine bibliometric properties to cover printed publications as well as electronic journals within broader keywords. In addition, it is recommended for researchers in the field of health tourism to conduct integrated research with different researchers from different study fields related to health tourism, especially where foreign resources are more preferred. 